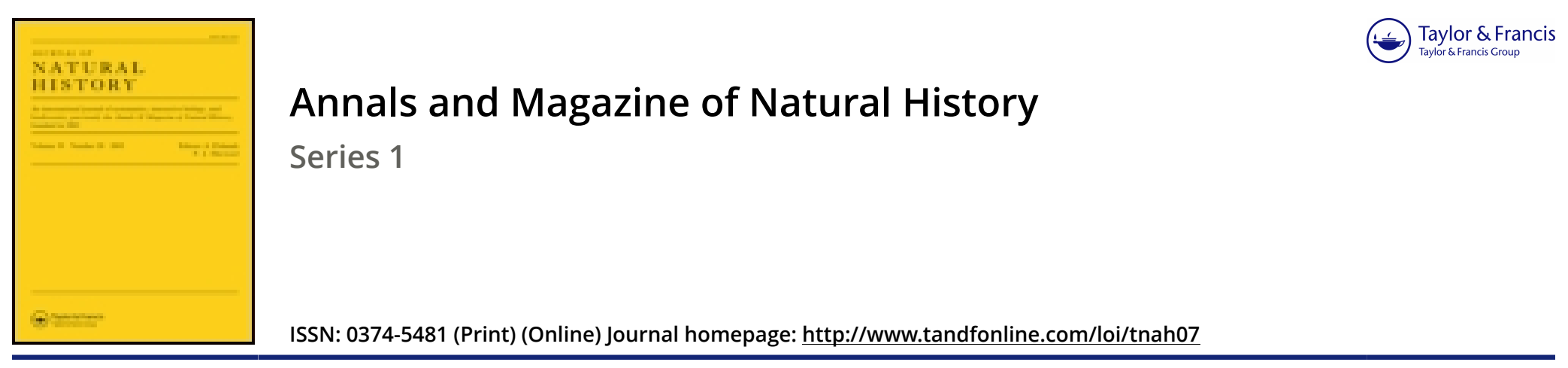

\title{
XVIII.-Contributions to the Natural History of Ireland
}

William Thompson Esq.

To cite this article: William Thompson Esq. (1838) XVIII._Contributions to the Natural History of Ireland , Annals and Magazine of Natural History, 1:3, 181-195, DOI:

10.1080/00222933809512266

To link to this article: http://dx.doi.org/10.1080/00222933809512266

曲 Published online: 15 Mar 2010.

Submit your article to this journal $[\pi$

Q View related articles $\longleftarrow$ 
lected a few specimens of a digitate-leaved species of $\mathrm{Mi}$ kania.

$\mathrm{U}_{\mathrm{p}}$ to the beginning of June I still continued to add to my stock of dried specimens, and on the 9th of that month left the mountains, with all my collections, for the city of Rio de Janeiro.

Rio de Janeiro, July 14th, 1837.

Geo, Gardner.

XVIII.-Contributions to the Natural History of Ireland. By William Thompson, Esq., Vice-President of the Belfast Natural History Society.

No. 6.-On the Birds of the Order Insessores.

[Continued from p. 26.]

The Pied Wagtail, Motacilla alba, Linn.*-Is a common species in this country, and though said to leave the northern to winter in the southern parts of England, is in the northern counties of Ireland permanently resident. One disposition towards a movement may however be witnessed, which is their collecting in the autumn in flocks, commonly consisting of about thirty individuals. Thus have I seen them at the end of September, on the borders of Lough Neagh, and have so observed them come to roost upon the reeds (Arundo phragmitis,) and the adjacent ground, on the banks of the river Lagan, until after the middle of November; but I am not aware whether the portion of these birds so congregated ever move southwards. Mr. R. Ball has likewise observed them in large flocks in the south of Ireland about Youghal, during the month of October. Towards the end of January the song of the wagtail is frequently heard in the north, and occasionally

* The pied wagtail of Ireland is identical with the $M$. alba of British authors generally, and with the $\boldsymbol{M}$. Yarrelli of Mr. Gould. By this author a new name has been applied to it, as he states, in consequence of a species peculiar to the temperate portion of continental Europe being the true $M$. "lba of Linnzus, and from which the British species is distinct. (Mag.
Nat. Hist. vol. i. p. 459, New Series.) The two characters which form the description of $\boldsymbol{M}$. alba in the 'Systema Naturæ,' are found in our bird. 'These are " pectorc nigro, rectricibus duabus lateralibus dimidiato oblique
albis," t. i. p.331, 13th ed. 
so late as in October. The situations generally known to me as selected for its nest were on the ground beneath piles of loosely heaped stones, the eggs four in number, and as described by Mr. Selby. A nest examined by my relative was, excepting some thread and bits of cloth in its foundation, entirely formed of cow and horse hair.

Montagu remarks of this species (Orn. Dict.), "as the weather becomes severe, they haunt marshes subject to the flow of the tide. In such places on the coast we have seen them in abundance, when none were to be found inland." In the north of Ireland they are always to be met with in the interior of the country, and in the most genial seasons of the year frequent the sea-side when the tide has ebbed. Like the dunlin (Tringa variabilis), and birds of similar habits, I have in some localities observed them daily attend upon the flowing tide in autumn. During the breeding season they have occurred to me on small and low rocky islets in the sea.

The wagtails are very gcneral favourites. It is interesting to observe their confidence in man, which is especially shown in their closely following and keeping pace with the plough and harrow, when the loud calling of the driver to his horses or other noise they heed not, as if knowing it is not addressed to them. In thus feeding, one manner only of taking their prey is resorted to; but elsewhere, when winged insects are the objects of pursuit, we may see in addition to running, both leaping and flying adopted; in the last they resemble the spotted fly-catcher, and through the air $I$ have seen them pursue insects as far as this species. It is amusing to behold what appears to be their playfulness of manner towards other birds, and the reception it meets with from them. Thus have I seen one fly out to sea after a king plover (Charadrius Hiaticula), and strike at it several times, the latter exerting all its powers to avoid it, as if the wagtail, not more than half its weight, were a bird of prey. Again, when one of these birds and a yellow bunting were feeding near each other, the wagtail gave chase to the latter, and after taking many turns, through all of which they maintained a regular distance of about a foot from cach other, they alighted peaceably on the same stone; the chase thus seeming to have been undertaken for 
mere diversion. On another occasion I saw a pair of wagtails pursue, to its great annoyance, a poor bat (Vespertilio Pipistrel$l u s$ ?) that untowardly appeared during one of the dark days of December (9th, 1832).

Gray Wagrain, Motacilla Boarula, Linn.-This beautiful and graceful species, though much less common than the last, is extensively, but not universally distributed over Ireland. Like the pied wagtail it is permanently resident throughout the country, whilst in the north of England it is known only as a summer, and in the south* (in general terms) as a winter visitor. For many years I have remarked its presence during every winter in the counties of Down and Antrim, and about the mountain rivulets as well as those adjacent to the sea. When by frost and snow the woodcocks have been driven from the mountain heaths to the covers, and the snipes from the marshes to the unfrozen springs, I have observed the gray wagtail in its summer haunts about the ponds at the mountainous locality of Wolfhill. At this season and late in the autumn it is occasionally seen in places of a very different character-in the extensive tan-yards, \&c. of Belfast.

The situations generally selected for the nest are holes in walls, those of bridges, about mill-wheels, or otherwise contiguous to water being preferred. In the romantic glens they also build, and for this purpose a pair generally resorts to a fissure of the rock beside a picturesque cascade at "the Falls," just such a place as would be chosen by the water-ouzel. On the 18th of March my relative has observed a pair of these birds apparently contemplating nidification, by minutely examining their former breeding haunts, and on the 12th of May has seen the young of the first brood on wing, though still requiring their parents' aid to feed them. The nest is generally formed of grasses and lined with horse-hair. I have invariably remarked the female as well as the male to possess the black mark on the throat in the nuptial season. After Montagu and Selby it may seem unnecessary to allude to this, but Temminck's having described it as characteristic of the male only,

- On August 28th I saw it in the gravelly bed of the river at Dole in France. In the third week of March I have rcmarked it at Ogley Pool, North Wales. 
has induced the observation. Throughout the winter the gray wagtail generally keeps in pairs; in autumn only have I seen a whole family, and never more together. Their prey is taken by the different methods described in the notice of the last species. About the head of mountain springs I have frequently observed this attractive bird, but knew not the object of its pursuit in these interesting spots, until the examination of the stomach of one in the month of December proved it, at least in one instance, to have been the minute river limpet, Ancylus fluviatilis, of which it contained many specimens. In so far as the haunts of $M$. alba and $M$. Boarula are regarded, I cannot see the advantage of Cuvier's division of the wagtails into two genera. Under Budytes, a name suggested by its being often seen among cattle (Règ. An. t. i. p. 391, 2nd ed.), he ranks the gray, and under Motacilla, which is stated generally to be seen about waters, is classed the pied; but, according to my observation, if either bird should in general terms be described as frequenting pastures, and hunting insects among the flocks, it should be the $M$. alba; and if hunting the vicinity of waters should be regarded as characteristic of the one rather than the other, it should be of the $M$. Boarula. The "form" of $M$. flava renders the propriety of his sub-genus more obvious.

Yellow Wagtail, Motacilla flava, Ray.-Mr. Templeton has remarked that this species is "a rare summer visitant, appearing more commonly about Lough Neagh than elsewhere." From the observations of ornithologists in various parts of the country, it seems to be generally a rare species. To myself it has in Ireland* occurred but once in a wild state, on June 24, 1832, in a turf bog on the confines of the county Donegal, a few miles from the city of Londonderry. But once has it been seen by Wm. Sinclaire, Esq., when, on $\Lambda$ pril 28, 1833, a single individual appeared, and on that day only, at "The Falls." In the collection of T. W. Warren, Esq. of Dublin, I have seen a specimen $\dagger$ which was shot at Finglass, near that city,

* In England I have seen it in the mouth of July about the lakes of II awes-water and Windermere.

+ This is the true $M$. flava as distinguished from the $M$. neglecta of Gould. 
about the 20th of April, 1835 : it is the only individual that has come under this gentleman's observation. A specimen set up by Mr. Wm. S. Wall, of Dublin, is stated to have been shot in the vicinity of the Custom-house in May, 1837. In the southern counties of Cork and Kerry it has not been met with by my correspondents.

Meadow Pipit, Anthus pratensis, Bechst.-This bird is very common in Ireland, from the meadows adjacent to the seashore, and occasionally the shore itself, to the mountain tracts of the very greatest elevation. It is permanently resident, but suffers much from severe frost and snow, and during such times is occasionally driven for food to the streets of Belfast, where it has been noticed after even two nights of frost. I once saw a meadow pipit walk into the sea and deliberately give itself a complete washing. It is mentioned by my relative that one of these birds feigned being wounded for the purpose of withdrawing his attention from its nest. My friend at Cromac has frequently found the nest of the meadow pipit on the banks of water-courses and drains, as well as on the ground in fields. One which was known to him at the side of a drain was discovered by some bird-nesting boys, who pulled the grass away that concealed it. On visiting it the next day, he observed a quantity of withered grass laid regularly across the nest; on removing this, which from its contrast in colour with the surrounding herbage he considered must have been placed here as a mark by the boys, the bird flew off the nest; and on his returning the following day he found the grass similarly placed, and perceived a small aperture beneath it, by which the bird took its departure, thus indicating that the screen which harmonized so ill with the surrounding verdure had been brought there by the bird itself. The same gentleman once introduced the egg of a hedge accentor into a meadow pipit's nest, containing two of its own eggs; but after a third egg was laid, the nest was abandoned.

The stomach of one of these birds, examined by me in December, was chiefly filled with minute coleopterous insects, but also contained worms, minute fragments of brick, and two perfect spccimens of the shell Bulimus lubricus. This pipit 
is conmonly called "moss cheeper" in the north; by the name of "we keên" it is known in Kerry*.

Rock Pipit, Anthus aquaticus, Bechst.-Although this species does not appear, in Mr. Templeton's published Catalogue of the Irish Vertebrata, known to his father (Mag. Nat. Hist., vol. i. new series), I find by reference to the MS. that he was acquainted with it. Under the name of Alauda petrosa it is remarked, "common about the rocks on the shore." The rock pipit is found on the coasts of Ireland throughout the year, and has on those af the north, west, south, and east occurred to me. It is nowhere more plentiful than about the rocky marine islets, of which the south islands of Arran, by reason of their extreme western position (off the coast of Clare), may be particularised.

With the following observations of Montagu my own entirely agree. He remarks of the rock pipit that "it seems wholly confined to the neighbourhood of the sea, and is never found, even in winter, more remote than the contiguous marshes within the occasional influx of the tide, depending chiefly on marine insects for its subsistence, and has never been observed to be gregarious." (Art. Rock Lark in Orn. Dict.) Mr. Selby has observed it to be "strictly confined to the rocky and abrupt shores :" (Ill. Brit. Orn., vol. i. p. 259.) but close to the town of Belfast it frequents a coast of the very opposite character, as on the lowest and most oozy part of the beach ; it may always be seen about the rejectamenta of the tide, consisting chiefly, in the situation alluded to, of the Zostera marina, the accumulated masses of which form the chief

- Anthus arborezs, Bechst. On April 12, 1827, I for some time gave attention to a bird at "The Falls," that, for general appearance, manner of singing, \&c., as described by Mr. Selby, I concluded must be this species. One or two ornithological friends have likewise similarly seen a pipit, which they presumed to be the $A$. arboreus, but specimens have not been obtained for examination that its identity might be determined. It is probably the tree pipit that is alluded to in the following passage from Smith's History of Cork, published in 1774 (p. 338, 2nd ed.): "The Alauda pratorum, Aldrov., or titlark, which is in England a bird of passage, is a stranger to Ireland. Dr. Rutly informs me that an eminent bird-catcher is now illtroducing them as a novelty in Dublin, being much esteemed for their sweet note. Another species, called the pippit or Alauda minor, whose legs are yellow, and a smaller kind of lark, is a constant attendaut to the cuckoo, as a good bird-cateher assures us." 
attraction. To stony embankments, piers, and similar erections it is likewise partial. These Temminck mentions it to frequent in Holland; but part of his remarks on the Anthus aquaticus are very different from those of British authors*. In pursuit of food we find most of the true shore birds (Grallatores) frequenting the bare beach, whether oozy, gravelly, or sandy, but the rock pipit generally seeks its sustenance either on the masses of seaweed which when growing are exposed at ebb-tide, or on those which have been cast ashore.

When looking for the nests of terns upon the Mew Island, off the coast of Down, on the 13th of June, I discovered one of the rock pipit; this was entirely composed of fine grasses, which also served for lining. It was on the ground, at the base of a narrow ledge of rock, and contained three eggs; these were greenish white, closely and pretty uniformly speckled all over with pale brown. The specimens of this bird, which I have critically examined, correspond with Temminck's description of the young birds of the year.

The Wheat-Ear, Saxicola Enanthe, Bechst.-Is a regular summer visitor to and commonly distributed over Ireland and the surrounding islands. Nowhere have I observed it in greater numbers than in the extreme north-west; and when visiting the largest of the south islands of Arran on the 8th of July, 1834, accompanied by Robert Ball, Esq., it was the only land bird of passage we met with. In the north the wheat-ear is generally the earliest of the summer birds in its arrival, appearing in the last week of March ; to this, however, the late spring of 1837 proved an exception, the 15th of April being the earliest date of its occurrence known to me about Belfast. By my correspondent in Kerry it has not been seen before the 25th of March. Although it is not the disposition of this species to congregate, about a dozen were on April the 3rd, 1836, observed together contiguous to the sea near Belfast,

- 'Temminck observes under "Habite: particulièrement le midi de l'Europe, où il niche; seulement de passage dans les provinces tempérées, le long des bordes des eaux et des fleuves, aux environs de Paris. Niche dans les pays en montagnes, même sur les plateaux stériles de celles qui sont très-élevées, comme les Pyrénécs et autres; plus rarement sur les falaises et sur les rocs qui bordent la mer." Man. Orn. Eur., part $1, p$. 267,2 nd ed. Again, in Part 3 of this work it is remarked, "Vit en Suisse et sur le Rlin," p. 189. 
and from so appearing at this season they had very probably migrated in company. Throughout our wild mountain pastures, as well as the rabbit-burrows and sand-hills that skirt the coast, the wheat-ear is found in its season, and in the first-mentioned localities, where even at the most genial period of the year we see but few of the feathered tribe, is highly attractive from the beauty of its plumage, lively habits, and variously uttered song. In such situations it nestles in old stone walls. The eggs I have examined, in form, size, and colour strongly resemble those of the hedge accentor, but on minute inspection differ from the uniform bluish-green colour of the eggs of this species, in being faintly speckled with very light brown.

During the first week of October I have seen wheat-ears in the vicinity of the sea in Downshire, but have never known any to be met with in the winter, as they are "in many parts of the south of England" (White's Selborne, p. 257, \&c. ed. 1837); nor are they ever specially looked after for the table in the north of Ireland; indeed, for this purpose the species does not appear here in sufficient numbers. In his Natural History of the county of Dublin, Rutly remarks that "it is excellent food and very fat, and for its delicacy is by some called the Irish ortolan" (vol. i. p. 313).

The Whin-Chat, Saxicola Rubetra, Bechst.-Like the wheat-ear, is a regular summer visitant to this country, but is much less diffused; besides, its places of resort contribute to render it still less known than, as a regular bird of passage, it might be. These about Belfast are chiefly the base of the mountains and the adjacent fields. It is in the north of Ireland, as elsewhere in the British Islands, considerably later in its arrival than the wheat-ear. In Mr. Stewart's catalogue it is described as common in Donegal*, and so it is also stated by Mr. Neligan to be in Kerry. This gentleman has remarked to me that the whin-chat is very partial to alighting on docks (Rumex) in the meadows it frequents, and that every summer it resorts to the same fields. In 1832 and 1833 the whin-chat was seen by the Rev. T. Knox about Killaloe, where he consi-

* From the adjoining county of Fcrmanagh, as well as in Donegal, I have secn specimens. 
ders it rare. The stomach of one which came under his inspection was, excepting a caterpillar, filled with flies and beetles.

The Stone-Chat, Saxicola Rubicola, Bechst.-Is resident and common throughout Ireland. Around Belfast it equally frequents the old ditch-banks, covered with the sloe and other shrubby plants, that surround the lowest-lying meadows, and the furze, or whins, or other cover on the mountain sides. In the earliest of the mild days of spring its song is heard. At the end of April I have seen the parents carry food to their young. My friend at Cromac has found its nests both in low bushes and on the ground, but only once in the latter situation. The stomach of one of these birds, sent to me in December, was entirely filled with minute coleopterous insects. Temminck remarks that the stone-chat is resident in Africa, but in Europe is a bird of passage.

Great Titmouse, Parus major, Linn.-This is a common species in Ireland, and is resident, like all the other titmice found in the country. Town plantations, as well as those in the country, are frequented by this bird. I have also remarked it in districts destitute of trees, and where whitethorn hedges afforded it the only shelter. Soon after the middle of December its song is generally commenced in the north. During last winter a pair of these birds, along with two blue titmice, daily visited the window-sill of a friend's house in the country, at a particular hour, when crumbs of bread were left there for them. The latter species only has renewed its visits in the present winter. The stomach of a Parus major, examined by me at the end of March, contained some seeds and the remains of coleopterous insects.

Blue Titmouse, Parus cceruleus, Linn.-This is the most common species of titmouse in Ireland. In the ordinary places of resort its lively and varied attitudes have often been described. In winter, whether mild or otherwise, this species is very partial to the reeds fringing the river Lagan. The force of one of these birds flying upon a reed sways it with a graceful bend almost to the water, in which the lower portion is immersed, but the bird nevertheless retains its grasp; then betaking itself to another, rapidly runs up its stem from near the base to its point, and almost dips into the river again. In 
addition to its more ordinary haunts it feeds pretty much on the highways, and occasionally builds in the walls of town gardens.

These birds are known to suffer considerably from the cold of winter, and when kept in the house are also very sensible to it. One in the possession of my friend at "the Falls," when let out of the cage in summer roosted upon its top; but in winter, although in a warm room, selected the hottest place for the night in which it could remain in safety, roosting under the fender, which afforded it at the same time sufficient space and shelter. This bird is from its familiarity and vivacity most amusing. Its cage is covered with close netting, which it has several times cut through and effected its escape into the room, when it flies to the children, and if taking hold of a piece of bread or cake in the hand of the youngest, will not forego the object of attack, though shaken with the greatest force the child can exert, and on one occasion so persecuted her for a piece of apple that she ran crying out of the apartment. It is especially fond of lump sugar. Confined in the same cage with it are some other birds, and amongst them a redbreast, which it has sometimes annoyed so much as to bring upon its head several chastisements, but in such cases the redbreast acted only on the defensive. Its favourite trick is to pull the feathers out of its fellow prisoners, and by so doing, it sadly tormented the young willow wren before mentioned, and made the same attempt even on a song thrush lately introduced to its domicile, but by this bird it was successfully repelled. It escaped out of doors several times, but always returned without being sought for. The titmouse often falls a victim to ignorance in this country as it does in England, in consequence of the injury it is supposed to do to fruit trees. Mr. Selby most justly pleads in favour of its being a friend rather than an enemy to the horticulturist; and Mr. Knapp, treating of the species very fully in his most agreeable manner, is indignant that it should in these days be ranked as vermin, and a reward be offered for its head. In the stomachs of two specimens killed in March and December, I found coleopterous and other insects. "Blue-bonnet" is the common name of this species in the north of Ireland.

Marsir 'Titmouse, Parus palustris, Linn.-In Smith's 
History of the County of Cork it is remarked, "Besides this species (Parus major), there is also the cole titmouse, the blackcap, the blue titmouse or nun, and the long-tailed titmouse" (vol. ii. p. 340, 2nd edit.). If we take for granted that the term "black-cap" is correctly applied to a Parus, the marsh titmouse must be considered the one that is meant. This species is not commonly distributed in Ireland. In a very few instances only has it occurred to me around Belfast, and not in any other locality. By two ornithological friends it has been met with but once or twice, and though within a few miles of the town, the localities and times of appearance were always different. By R. Ball, Esq., it has been seen only about Ballitore in the county of Kildare. In the collection of T.W. Warren, Esq., a native specimen is preserved, which was shot in the Phonix Park near that city.

Cole Trmouse, Parus ater, Linn.-Montagu and Selby state that this species is less numerous in England than the $P$. palustris, but in Ireland the relative proportion of the two species is very different. To one only of my correspondents is the latter known with certainty, but all who have bestowed much attention on the subject attest the presence of the cole titmouse in their respective counties, viz. Donegal, Clare, Kerry, Cork, Tipperary, and Dublin. In the north generally, and wherever I have been in suitable localities throughout the country, it has occurred pretty commonly. Seeds as well as insects, \&c. form a portion of its food. In a plantation consisting chiefly of the common pine (Pinus sylvestris) and the alder, $I$ once in the middle of December for a considerable time observed some of these birds, accompanied by the goldcrested regulus and lesser redpole (Fringilla Linaria). They were all occupied in flying from one alder to another, and were intent on procuring the seed of this tree only. The various attitudes of these three beautiful species were highly interesting, as the light bunch of pendent seed admitted not of their being stationary for a single moment. To observe a troop of titmice comprising three or four species, in addition to the gold-crested regulus, and occasionally one or two others of our smallest birds, moving about in company, now pausing as if to display their graceful attitudes on a few adjacent trees, then filing rapidly through the thickest plantations with the esprit 
du corps of one species, has always been to me, but especially in the wintry wood, a source of much attraction, and at such times their shrill little notes, evidently more than sight, serves to keep them together. The following note appears in my journal under the date of November 19, 1833:-Being in Colin Glen to-day, I as a matter of course saw the gold-crested regulus and the blue and cole titmice in company. I was amused on observing both species of Parus cling to the centre of the under side of the leaves of the sycamore (Acer Pseudo-Platanus) still attached to the trees, and describe a circle with their bills by picking with extreme rapidity all round them, during which operation their weight brought not to the ground a single leaf, though all were "sere and yellow." The stomach of one of these birds which came under my inspection at the end of March, in addition to fragments of stone, contained only seeds.

Long-talled Titmouse, Parus caudatus, Linn.-This interesting bird, though not a well-known species in consequence of its retired and wooded haunts, has long since been recorded as indigenous to Ireland; and as such, appears in the county histories of Cork (Smith's) and Londonderry. Rutly in his Natural History of Dublin remarks, that it " was found in the county in the winter of $1768 . "$ It is at present less known in the south than in the north; over which it is diffused, but not very plentifully. None of my correspondents resident in the province of Munster have seen this bird in its native haunts; but in the vicinity of Cahir, county of Tipperary, it is stated to occur. Mr. R. Ball observes, that the long-tailed titmouse is not uncommon about Dublin, though around Youghal, his former place of residence, he never met with it. Of late years its numbers seem to have increased considerably throughout the north*. To the late Mr. Templeton it occurred only twice; but within several miles around Belfast this titmouse has for some years past been seen wherever there is a sufficiently great extent of wood, this alone being apparently the essential requisite to the species; as it equally inhabits the plantations of the mountain glen,

* At the same time their numbers fall greatly short of those of $P$. corrtleus, which in Mr. Sampson's catalogue of the Birds of Londonderry is said to be less frequent than the $P$. caudatus. 
those around the beautiful seats which adorn the shores of the bay and of the most highly improved demesnes in the valley of the Lagan : a family of these birds appear particularly interesting when flitting over the waters of the river and about the overhanging trees that border it. When the beautiful rosy hue of its breast is conspicuous, it adds much to the attraction of this species. The first of these birds I ever saw excited my attention by its peculiar note uttered when stationary, and though different from that of the others, had a generic similarity which satisfied me that it must proceed from some species of Parus. Its call when in motion is soft, thus differing from the shrill little voices of some of the same genus, with with it seems less to consort than with the goldcrested regulus.

On May 13, 1832, my relative describes, as an amusing spectacle, a pair of these birds, which he saw feeding seven young ones, which having left the nest were clustered together on the branch of a tree within the space of about six inches. The manner in which a family of long-tailed titmice crowd together for warmth during snow and in the cold wintry night has been well described; (vide Habits of Birds, p. 60, and note to p.171 of White's Selborne, ed. 1837,) but that it is the ordinary habit of the species, and not consequent on the piercing breath of winter, is indicated in the following note from my journal, under the date of July 5, 1833. Mr. Wm. Sinclaire remarks, that some days ago he was much entertained by ob. serving a family of about ten or twelve long-tailed titmice going to roost in company, when each individual endeavoured to get as near the middle of the group as possible, and that enviable situation was no sooner attained by a few than those from the outskirts used all their efforts to insinuate themselves between them, and foiled in this, next exerted their powers to avoid being placed outside-in all respects just the winter practice. A similar procedure on the part of the goldcrested regulus is described by Mr. Herbert in a note to White's Selborne, (p. 180, ed. 1837.). So many as twenty long-tailed titmice have twice been reported to me as seen in company. The stomach of one, which came under my examination in the month of January, was filled with insect food, of which some Ann. Nat. Hist. Vol. 1. No. 3. May 1838. 
minute beetles were perfect. M. Temminck describes the female only as having the black streak over the eyes; Mr. Jenyns considers it common to both sexes: in nine specimens of $P$. caudatus now before me, this marking is apparent, but in some individuals is much better defined than in others; in one only of them the sex was observed, when it proved to be a male bird: of this sex it may fairly be presumed are others of the remaining eight individuals*.

Bearded Titmouse, Parus biarmicus, Linn.-Of this bird I have never seen a native individual, and can only repeat the short notice of it as Irish communicated by me to the Zoological Society of London in 1834. " Mr. W. S. Wall, bird-preserver, Dublin, who is very conversant with British birds, assures me that he received a specimen of this Parus from the neighbourhood of the river Shannon a few years since." Zool. Proc., 1834, p. 30. Bewick's admirably characteristic woodcuts of birds are of constant reference with $\mathrm{Mr}$. Wall.

Bohemian WAX-Wing, Bombycivara garrula, Temm.Mr. Templeton has said of this bird: "Sometimes seen about Belfast, but more common in Tullamore Park, county Down; has been several times $\dagger$ shot in the county of Derry." Mag. Nat. Hist., vol. i. p. 405, N.S. By a veteran sporting friend the wax-wing has twice been obtained in the neighbourhood of Belfast, and in both instances in wooded glens within the district of the Falls. One of these birds was shot rather more than twenty years ago, and the other considerably before that time, and when severe frost and snow prevailed. Mr. R. Ball informs me, that about 1820, one was killed at Castle Martyr, in the county of Cork. "In the winter of 1822-23, a specimen of the Bombycilla Bohemica, Briss., was found dead in the woods of Burton Hall, in the county of Carlow." Zool. Journ., vol. i. p. 590. Dr. J. D. Marshall has noticed an indiviclual which was shot in the neighbourhood of Dublin in

* Families of the long-tailed titmouse have frequently been seen by a sporting friend on the wooded banks of the river Stincher in Ayrshire.

+ In the late Mr. Templeton's MS. the word "once" is used in the place of "several times" in the printed Catalogue. Another instance of the waxwing's occurrence in Ireland has been made known to me since the above was written. The specimen was shot about the winter of 1825.26 , in the Castlereagh Hills, county of Down. 
1829, Mag. Nat. Hist., vol. ii. p. 394. In the Belfast Newsletter of Dec. 20, 1831, the following paragraph appeared :"In the early part of last month a beautiful specimen of the 'Bohemian wax-wing (Bombycilla Bohemica, Briss.), was shot in Newtownlimavady. It was perched upon a rowan tree in a garden, and seemed busily employed in picking off the berries; many of them were found in its eraw when it was opened." In the collection of Dr. R. Graves of Dublin, I have seen one which was killed in Ireland. On Feb. 6, 1835*, an extremely beautiful individual of this species was shot in a garden at Ballymacarret, in the suburbs of Belfast, and on the following day another was seen at the same place. The former, which came under my inspection, proved on dissection to be a female ; its stomach, which I did not examine until the 10th, four days after its death, was entirely filled with the hairs of the white-thorn (Cratagus Oxyacantha), which possessed an odour as fresh as if just plucked from the tree. Each wing exhibited six plumelets, with their scarlet wax-like adornments; some authors have described the female as wanting these altogether, and the greatest number $I$ have seen attributed to her are four or five. (Temm.) In a few other instances, but without particulars, I have had reports of the wax-wing's occurrence in Ireland.

XIX.-On a New English Species of Urtica. By Charles C. Babington, M.A., F.L.S., F.G.S., \&c.

Aт a recent meeting of the Cambridge Ray Club my attention was drawn (by the Rev. Dr. Jermyn, to the fact, that two very distinct plants existed in our native herbaria under the name of Urtica pilulifera, Linn., and I can only account for our not having previously observed their differences from the circumstance, that English specimens of the true plant of Linnæus do not exist in the collections of Cambridge botanists.

Upon further examination I was much pleased by finding that one of these plants was the true U. pilulifera, and that

* Just at this time a spccimen was mentioned in the papers to have been shot near Alcester in England. 